\title{
Symbiotic associations between anthozoans and crustaceans in a temperate coastal area
}

\author{
L. G. Jonsson ${ }^{1, *}$, T. Lundälv ${ }^{2}$, K. Johannesson ${ }^{1}$ \\ ${ }^{1}$ Department of Marine Ecology, Göteborg University, Tjärnö Marine Biological Laboratory, 45296 Strömstad, Sweden \\ ${ }^{2}$ Tjärnö Marine Biological Laboratory, 45296 Strömstad, Sweden
}

\begin{abstract}
While symbiotic associations between anemones and crustaceans appear to be common in tropical waters, few such associations are known from temperate waters, except for the symbiosis between hermit crabs and anemones. In this study, observations made with ROVs (remotely operated vehicles) suggested that certain shrimps (Pandalus borealis, P. propinquus, P. montagui and in particular Spirontocaris liljeborgii and Lebbeus polaris) associate with the anemone Bolocera tuediae and the cerianthid Pachycerianthus multiplicatus by aggregating beneath their tentacles. The lithodid crab Lithodes maja was also observed associating with $B$. tuediae. Laboratory experiments suggested that female crabs have a stronger association than males. The associations are presumably facultative commensalistic, as the species of crustaceans live as non-symbionts on the sea floor as well, and the 2 anthozoans do not seem to gain any benefits from the associations. In the field, $S$. liljeborgii had the closest association with both species of anthozoans, while $B$. tuediae was the preferred host of all associating species. The main benefit for the crustaceans to be associated with the anthozoans is protection against predators. In the case of the shrimps, access to a food source is probably also important.
\end{abstract}

KEY WORDS: ROV $\cdot$ Commensalism - Symbiosis $\cdot$ Bolocera tuediae Pachycerianthus multiplicatus Spirontocaris liljeborgii $\cdot$ Lebbeus polaris $\cdot$ Lithodes maja $\cdot$ Pandalus spp.

\section{INTRODUCTION}

Symbioses between anemones and crustaceans are rarely reported from temperate waters, while common in tropical waters. The small number of observed associations may be due to different physical and biological conditions in temperate waters that could make symbiosis a less profitable strategy than in tropical waters. Another explanation for the scarcity of observed associations in temperate waters may be that existing symbioses have been overlooked because of the difficulties in observing them, particularly in deep-water habitats. The only well-known symbiosis between anemones and crustaceans from temperate waters is that between hermit crabs and the species of anemones they

${ }^{*}$ E-mail: lisbeth.jonsson@tmbl.gu.se carry on their shells (Ross 1971, Shick 1991). Vader $(1970 \mathrm{a}, \mathrm{b})$, however, found symbiotic associations in Norwegian waters between Bolocera tuediae Gosse, 1860 and amphipods and copepods. Howard (1982) reported that Pandalus borealis Kröyer, 1838, formed clusters around B. tuediae, and recently Stevens \& Anderson (1999) observed hippolytid and pandalid shrimps associated with the anemone Cribrinopsis fernaldi in Alaskan waters.

In this study we describe associations between 2 anthozoans and several species of decapod crustaceans in temperate benthic (60 to $250 \mathrm{~m}$ ) habitats in the Kosterfjord, off the Swedish west coast. Using video recordings with ROVs (remotely operated vehicles) from natural habitats and laboratory experiments we tested the hypothesis that shrimp of 5 different species (Spirontocaris liljeborgii Bate, 1888, Lebbeus polaris Sabine, 1824, Pandalus borealis, P. propinquus 
G.O. Sars, 1870, and P. montagui Leach, 1814) aggregate beneath, or immediately adjacent to 2 specific anthozoans common in the fjord, Bolocera tuediae and Pachycerianthus multiplicatus Roule, 1904. Similarly, we tested if the lithodid crab Lithodes maja Latreille, 1806 associates with $B$. tuediae.

\section{MATERIALS AND METHODS}

Bolocera tuediae is common on hard substrata (20 to $2000 \mathrm{~m}$ ) on both sides of the North Atlantic (Manuel 1981). Its maximum length and diameter are about 25 and $35 \mathrm{~cm}$ respectively. It has numerous large nematocysts on the column, tentacles, actinopharynx and mesenterial filaments (Vader 1970a). Field and aquarium observations indicate that it is a voracious predator, capturing not only plankton such as krill, Meganyctiphanes norvegica, and Sagitta spp., but also fishes (T.L. pers. obs.) and shrimp (M. Larsvik pers. comm.). Partly digested crustaceans (species of Pon-

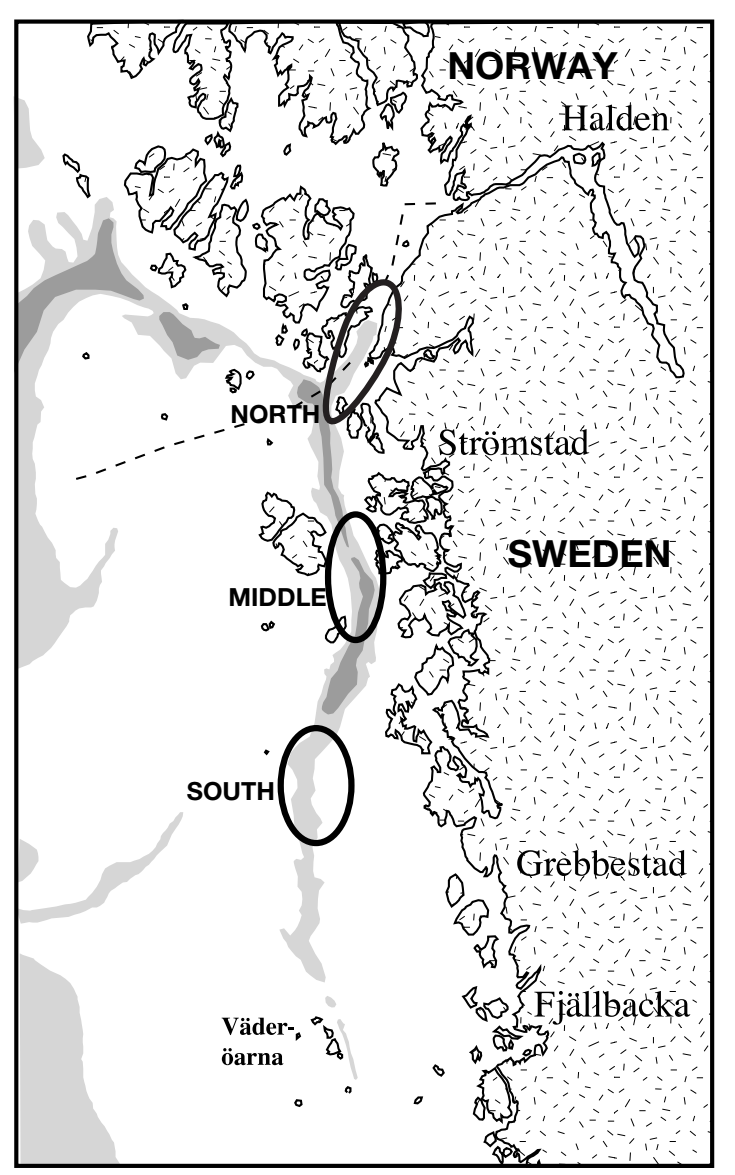

Fig. 1. Three areas (ringed) of the Kosterfjord northern west coast of Sweden, sampled with remotely operated vehicle (ROV technique) tophilus, Munida, Pandalus, Calacarides and Mysidacea) have regularly been found in the gastrovascular cavities of sampled specimens (Vader 1970a).

The cerianthid Pachycerianthus multiplicatus is found on soft bottoms (15 to $200 \mathrm{~m}$ ) around the coasts of western Scandinavia and around Scotland and Ireland (Manuel 1981). Its maximum length is about $160 \mathrm{~cm}$, of which the tube, buried in soft sediment, amounts to about $130 \mathrm{~cm}$. The diameter of the extended tentacles reaches about $30 \mathrm{~cm}$ (O'Connor et al. 1977). This species appears to be restricted to the capture of plankton such as Sagitta spp. (L.G.J. pers. obs.), but no larger prey, possibly because of weaker nematocysts than in Bolocera tuediae.

The 2 anthozoans Bolocera tuediae and Pachycerianthus multiplicatus are both abundant in the Kosterfjord. However, type of bottom substrate and microscale hydrographic conditions probably influence their rather patchy, small-scale distributions (L.G.J. pers. obs.).

Field studies. We examined 10 sites known to harbour populations of Bolocera tuediae and/or Pachycerianthus multiplicatus from 3 different areas of the Kosterfjord (Fig. 1). In each area, both species of anthozoans were recorded with a video camera, although the number of individuals of the 2 species differed greatly between the areas. A total of $56 \mathrm{~B}$. tuediae and 30 P. multiplicatus were recorded .

Most of the video recordings were done with a small ROV (max. depth $100 \mathrm{~m}$ ) with a high-quality camera that enabled identification of the shrimps. A large ROV (max. depth $300 \mathrm{~m}$ ) was used to assess the number of shrimps, without species identification, at depths greater than $100 \mathrm{~m}$. At each site, the ROV was manoeuvred close to the bottom over a roughly circular area (1800 to $2500 \mathrm{~m}^{2}$ ). Each encountered anemone or cerianthid was approached until all shrimp aggregated beneath or adjacent to it $(<0.5 \mathrm{~m})$ could be counted and identified to species.

Areas without anthozoans but representative of the same type of substratum and habitat were chosen at random at about $5 \mathrm{~m}$ from each sampled anthozoan; these control areas were of similar size to the areas observed around each anthozoan. We recorded numbers of shrimp at each control area using the same number of control areas as those with anthozoans. We also recorded the number of crabs (Lithodes maja) hiding beneath the feeding tentacles of the anemone Bolocera tuediae, as well as in other habitats.

Laboratory crab experiments. To test whether or not the crab Lithodes maja seeks shelter and, if so, prefers Bolocera tuediae to an artificial model, a B. tuediae was placed at one end and an artifical anemone at the other end of a large aquarium. The area of the aquarium was divided into 3 sections: (1) around or beneath the artificial anemone; (2) around or beneath $B$. tue- 
diae; $(3)$ in the middle of the aquarium with no available shelter; this middle area was equal to half the area of the aquarium.

The anemone used measured about $20 \mathrm{~cm}$ from the base of the column to the tips of the tentacles when active. The artificial anemone had the same shape and size as the true anemone, but lacked nematocysts. The base of the artificial anemone was made of concrete and buried in the coarse sand covering the bottom of the aquarium. A thick plastic tube served as a column and 2 different kinds of ropes as tentacles; 1 type hung down along the column, the other floated above the column in the water. The fibres of both ropes were unwound to create the impression of a multitude of tentacles.

One Lithodes maja at a time was released in the middle of the aquarium, facing 1 of the long sides. After $2 \mathrm{~h}$ we noted the position of the crab: we considered this period sufficient to allow the crab to explore the aquarium and select its preferred position. A total of $18 \mathrm{crabs}$ (9 males and 9 females) were used. Each crab was tested twice, and we switched the positions of Bolocera tuedie and the artificial sea anemone each time to control for effects of light direction.

Laboratory shrimp experiments. Shrimps for the experiment were captured in a small trawl, deployed for only a few minutes at a time, and emptied directly into big containers on deck. The shrimps were captured in darkness to prevent light-damage to their eyes. In the experimental room dim light was used. Only Pandalus borealis was used, as no other shrimps were captured with the trawl.

The same laboratory set-up as for the crab experiment was used for the shrimp, except that a dim light was placed above the centre of the aquarium. Furthermore, we tried to induce shrimp activity by continuously adding water from an aquarium containing cod and saithe to the middle of the experimental aquarium (both these fishes are predators of Pandalus borealis). The positions of the shrimp were noted after $1 \mathrm{~h}$. Seventy $P$. borealis, released 10 at a time, were used in the experiment.

Statistical evaluation. Analysis of variance (ANOVA: see e.g. Underwood 1997) tested the effect of 1 or more factors on the number of crustaceans in the field studies. In all tests, the data set was balanced by random exclusion of data. In data sets with heterogeneous variances (determined by Cochran's $C$-test) log-transformation of data was used in most cases to produce homogeneus variances (other transformations are indicated where relevant). Each factor of a test was considered either fixed or random, and the F-ratio was calculated accordingly (Underwood 1997). For the laboratory habitat-choice experiments, a replicated goodness-of-fit test with William's correction (Sokal \& Rohlf
1995) evaluated the results in relation to the nullhypothesis prediction (the null prediction being a random distribution of crustaceans over the areas of the experimental aquaria).

\section{RESULTS}

\section{Field studies}

Eighty-six anthozoans were video-recorded (Tables 1 \& 2). All observed Bolocera tuediae (56 anemones: Table 1) and $93 \%$ of the Pachycerianthus multiplicatus (28 cerianthids: Table 2) had shrimp, aggregating beneath them. Shrimps were never observed associated with anemones of other species (Urticina felina, U. eques, Actinostola callosa).

Area and the interaction between area and habitat had no effect on shrimp number (all species), while habitat alone influenced the number of shrimps (Table 3, Fig. 2). The shrimps chose either of the 2 anthozoans rather than the control habitat $(\mathrm{p}<0.05$, Student-Newman-Keuls post-hoc test).

As there was no difference between the 3 study areas with respect to the association between anthozoans and shrimps, the data from all areas were pooled. Instead, we distinguished subareas with dense populations of anthozoans ( $\geq 4$ individuals of anthozoan per 30 min ROV filming) from those with sparse populations ( $<2$ anthozoans per 30 min filming). Anthozoan density did not, however, affect the number of shrimps associated with individual anthozoans (Table 4).

Both anthozoan species were found in 5 of the sites. Comparing the mean number of shrimps associated with Bolocera tuediae with the numbers associated with Pachycerianthus multiplicatus showed that the shrimps preferred B. tuediae (mean $=13.7)$ to $P$. multiplicatus (mean $=2.9$; 1 -factor ANOVA, $\mathrm{p}=0.02$, $\mathrm{df}=9$ ).

To find out if host preferences differed among shrimps, we analysed each species separately, except for the 3 pandalids, which were pooled due to problems of separating these species on the video film. All shrimps preferred Bolocera tuediae to Pachycerianthus multiplicatus, but (as indicated by a significant interaction) to different degrees (Table 5). Spirontocaris liljeborgii and Pandalus spp. were associated with $B$. tuediae about 4 times as often as with $P$. multiplicatus, while Lebbeus polaris associated as much as about 42 times more with $B$. tuediae than with the cerianthid (Fig. 3). In this case, the original data were squareroot-transformed to fit the assumption of homogeneity of variances.

Altogether, 39 Lithodes maja were observed in the same areas as Bolocera tuediae and $72 \%$ of these (28 crabs) were found beneath $B$. tuediae. In areas with 
Table 1. Numbers of Bolocera tuediae and numbers of associated shrimp of 3 different genera. 'Shrimp' represents the number of shrimp observed with the large ROV when it was not possible to identify species. The total number of shrimp observed beneath or adjacent to $B$. tuediae and the total number observed in the control areas (see text) are indicated

\begin{tabular}{|lccccrrr|}
\hline Location & $\begin{array}{c}\text { Bolocera } \\
\text { tuediae }\end{array}$ & Shrimp & $\begin{array}{c}\text { Spirontocaris } \\
\text { liljeborgii }\end{array}$ & $\begin{array}{c}\text { Lebbeus } \\
\text { polaris }\end{array}$ & $\begin{array}{c}\text { Pandalus } \\
\text { spp. }\end{array}$ & $\begin{array}{c}\text { Total } \\
\text { shrimp }\end{array}$ \\
\hline North & 35 & 44 & 162 & 61 & 0 & 267 & \multicolumn{1}{c}{$\begin{array}{c}\text { Control } \\
\text { areas }\end{array}$} \\
Middle & 8 & 22 & 0 & 0 & 0 & 22 & 9 \\
South & 13 & 49 & 206 & 12 & 11 & 278 & 1 \\
Total & 56 & 115 & 368 & 73 & 11 & 567 \\
\hline
\end{tabular}

Table 2. Pachycerianthus multiplicatus. Numbers observed and numbers of associated shrimp of 3 genera. Further details as in Table 1

\begin{tabular}{|c|c|c|c|c|c|c|}
\hline Location & $\begin{array}{c}\text { Pachycerianthus } \\
\text { multiplicatus }\end{array}$ & $\begin{array}{c}\text { Spirontocaris } \\
\text { liljeborgii }\end{array}$ & $\begin{array}{l}\text { Lebbeus } \\
\text { polaris }\end{array}$ & $\begin{array}{l}\text { Pandalus } \\
\text { spp. }\end{array}$ & $\begin{array}{c}\text { Total } \\
\text { shrimp }\end{array}$ & $\begin{array}{c}\text { Control } \\
\text { areas }\end{array}$ \\
\hline North & 14 & 38 & 1 & 2 & 41 & 5 \\
\hline Middle & 13 & 31 & 0 & 0 & 31 & 3 \\
\hline South & 3 & 10 & 0 & 0 & 10 & 2 \\
\hline Total & 30 & 79 & 1 & 2 & 82 & 10 \\
\hline
\end{tabular}

Table 3. Two-way orthogonal ANOVA analysing effect of geographic location (random factor with 3 levels: north, middle and south part of Kosterfjord), choice of habitats by shrimps (fixed factor with 3 levels: Bolocera tuediae, Pachycerianthus multiplicatus and control area with no anthozoan), and interaction of geographic locations with habitat choices of the shrimps. Dependent variable $=\log$ number of shrimps associated with each anthozoan/control area

\begin{tabular}{|lccccc|}
\hline Source & df & MS & $F$ & $p$ & Error term \\
\hline Location & 2 & 0.29 & 1.26 & 0.31 & Residual \\
Choices of shrimps & 2 & 6.08 & 44.56 & 0.002 & Location $\times$ Choices \\
Location $\times$ Choices & 4 & 0.14 & 0.59 & 0.67 & Residual \\
Residual & 18 & 0.23 & & & \\
\hline
\end{tabular}

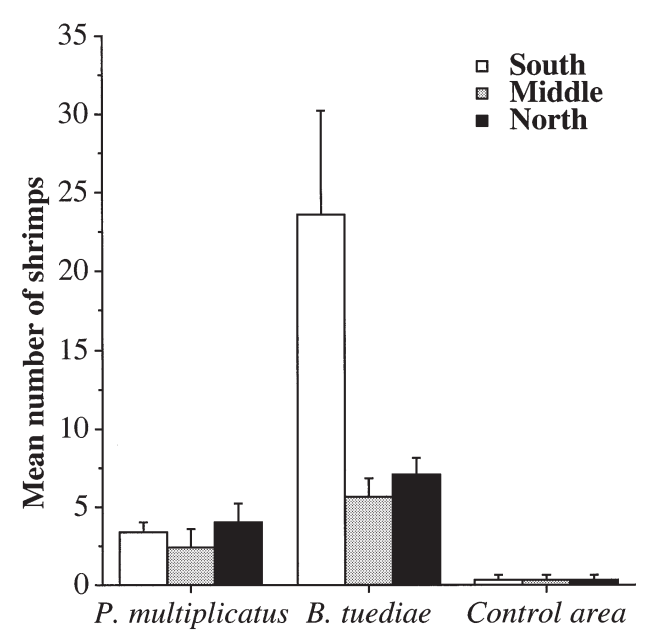

Habitats

Fig. 2. Number of shrimps (all species pooled, see 'Results: Field studies') associated with Pachycerianthus multiplicatus, Bolocera tuediae and the control areas of bare bottom in the 3 areas investigated no $B$. tuediae the crabs were sometimes observed close to stones or big sponges. On 6 occasions we found 2 or 3 L. maja beneath a single individual of $B$. tuediae, but generally only 1 crab was found beneath any 1 anemone.

\section{Crab experiments}

Of the 18 crabs 7 chose to shelter beneath the anemone when Bolocera tuediae was placed in the direction of the dim light. When the artificial anemone was closest to the light, 12 of the crabs chose $B$. tuediae. The difference between the results of the 2 setups was non-significant ( $p=0.08$, heterogeneity $G$ test). However, we could not reject the possibility that the crabs somewhat avoided the dim light, and we therefore used randomly chosen results from both setups in order to compensate for possible effects of the light. Although the average crab preferred natural and 
artificial anemones to bare substrate (replicated goodness-of-fit test with Williams's correction, $\mathrm{p}=0.0008$, $\mathrm{n}=18$, df =1), there was a striking difference between female and male crabs. The association behaviour was pronounced among the females $(p=0.0006, n=9)$, but absent, or nearly so, among the males $(p=0.23, n=9)$ (Table 6).

Of the crabs that sought shelter, 11 preferred the live anemone while 5 chose the artificial anemone $(\mathrm{p}=$ 0.13 , replicated goodness-of-fit test with Williams's correction). As a function of sex (9 females, 7 males), 7 females associated with the real and 2 with the artificial anemone $(p=0.09)$, while for the males the corresponding numbers were 4 and $3(\mathrm{p}=0.71)$. This suggests that females preferred the real Bolocera tuediae while males had no preference.

Table 4. Two-way orthogonal ANOVA analysing effect of 2 kinds of habitats (fixed factor with 2 levels: sparse or dense populations of anthozoans), and habitat choices of shrimps (factors as in Table 1). Dependent variable = log number of shrimps

\begin{tabular}{|lcccl|}
\hline Source & df & MS & $F$ & $p$ \\
\hline Choice of shrimps & 2 & 12.88 & 75.04 & 0.0001 \\
Type of biotope & 1 & 0.003 & 0.02 & 0.89 \\
Choice $\times$ Type & 2 & 0.20 & 1.15 & 0.32 \\
Residual & 69 & 0.17 & & \\
\hline
\end{tabular}

Table 5. Two-way orthogonal ANOVA analysing effect of host species (fixed factor with 2 levels: Bolocera tuediae and Pachycerianthus multiplicatus), shrimp species (fixed factor with 3 levels: Spirontocaris liljeborgii, Lebbeus polaris and Pandalus spp.), and the interaction between these 2 factors.

Dependent variable $=$ square root number of shrimps

\begin{tabular}{|lrrrl|}
\hline Source & df & \multicolumn{1}{c}{ MS } & \multicolumn{1}{c|}{$F$} & $\mathrm{p}$ \\
\hline Host species & 1 & 4.81 & 12.35 & 0.001 \\
Shrimp species & 2 & 29.40 & 75.53 & 0.0001 \\
Host sp. $\times$ Shrimp sp. & 2 & 2.39 & 6.15 & 0.004 \\
Residual & 48 & 0.39 & & \\
\hline
\end{tabular}

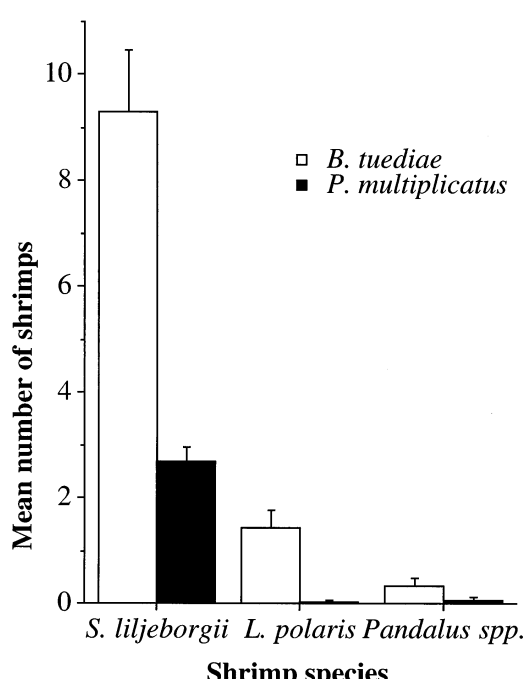

Fig. 3. Spirontocaris liljeborgii, Lebbeus polaris, Pandalus spp. Numbers of each shrimp species (species of Pandalus pooled) associated with Bolocera tuediae and Pachycerianthus multiplicatus. Data are means of all 3 areas

\section{Shrimp experiments}

The 7 replicate experiments displayed no heterogeneity of results and were thus pooled into 1 single test. Among the total of 70 shrimps, 24 associated with the real Bolocera tuediae, 15 stayed close to the artificial anemone and 31 preferred the bare sand. This distribution did not deviate significantly from a random distribution (replicated goodness-of-fit test with William's correction $\mathrm{p}=0.25, \mathrm{n}=70, \mathrm{df}=2$ )

\section{DISCUSSION}

In this study we show that several species of crustaceans associate with anthozoans in an area in the North Atlantic in a way similar to that in tropical waters. Our results suggest that crustacean-anthozoan symbioses are not exceptionally rare in temperate compared to tropical waters, but that traditional sampling techniques are inadequate for revealing these.

Table 6. Bolocera tuediae. Behaviour in laboratory experiment. Both observed and expected distributions are indicated. Replicated goodness-of-fitness tests were used to assess probability estimates

\begin{tabular}{|c|c|c|c|c|c|c|}
\hline & \multicolumn{2}{|c|}{ Total crabs $(\mathrm{n}=18)$} & \multicolumn{2}{|c|}{ Females $(\mathrm{n}=9)$} & \multicolumn{2}{|c|}{ Males $(\mathrm{n}=9)$} \\
\hline & Observed & Expected & Observed & Expected & Observed & Expected \\
\hline B. tuediae & 11 & 4.5 & 7 & 2.25 & 4 & 2.25 \\
\hline Artificial & 5 & 4.5 & 2 & 2.25 & 3 & 2.25 \\
\hline No shelter & 2 & 9 & 0 & 4.5 & 2 & 4.5 \\
\hline $\mathrm{p}$ & \multicolumn{2}{|c|}{0.0008} & \multicolumn{2}{|c|}{0.0006} & \multicolumn{2}{|c|}{0.23} \\
\hline
\end{tabular}


Roughgarden (1975) suggested 3 conditions necessary for a symbiotic association to evolve and for the symbionts to develop a dependency on the host: (1) the host should be easy to find; (2) host survival should not be affected by the symbiont; (3) the host should provide a substantial benefit to the symbiont. Furthermore, host-dependency increases with the importance and size of the benefits provided by the host and with the longevity of the host (Roughgarden 1975).

Both Bolocera tuediae and Pachycerianthus multiplicatus were abundant in the study areas and the former is considered to be extremely long-lived (Vader 1970a). Unfortunately, we have no information on the longevity of the latter. $B$. tuediae was preferred to $P$. multiplicatus as a host for all the shrimps observed. The anemone may provide better protection against predators than does the cerianthid, as the former seems to have stronger nematocysts. We also often observed the crab Lithodes maja beneath the canopy of the tentacles of a $B$. tuediae, but never beneath a $P$. multiplicatus. A few B. tuediae were observed in the field without any associated shrimp. One possible explanation is that the anemones had recently extended their tentacles after a period of contraction. Contracted anemones would not provide shrimps with sufficient shelter, and shrimps might then leave them to seek an anemone with extended tentacles. P. multiplicatus is not able to contract its tentacles (Dahl 1960), but instead withdraws its column into its tube when disturbed, so that the tentacles rest directly on the bottom substrate, thus leaving little space for any shrimp to hide.

Most of the shrimps associating with the anthozoans occupied fairly distinctive positions in relation to their host. Individuals of Spirontocaris liljeborgii were observed closest to the column and, in many cases, even on the column; in a few cases they were even found among the tentacles on the oral disc. Individuals of Pandalus spp., on the other hand, were typically found in a ring around the host outside $S$. liljeborgii. All the shrimp observed in the control areas were Pandalus spp. Individuals of Lebbeus polaris seemed more flexible, and were found at various distances from the anthozoan. Individual shrimp generally showed a radially oriented pattern, with heads pointing outwards from the anthozoan (cf. Stevens \& Anderson 1999).

Often, when video-recording a Bolocera tuediae, there was an abundance of krill Meganyctiphanes norvegica swimming around the anemone, probably attracted by the headlight from the ROV. Temporarily blinded by the light, they often swam straight into the tentacles of the anemone and were captured. The tentacles reacted strongly, by quickly curling the tips to ensure the catch. On the other hand, when individuals of Spirontocaris liljeborgii became entangled in the tentacles, they violently jerked backwards but quickly regained their normal position beneath the tentacles. This indicates that they were not harmed by the nematocysts. When contact with the tentacles was gentle, the shrimp did not seem to react. The anemone usually reacted to the contact with the shrimp by only a slight contraction of its tentacles, in clear contrast to its behaviour when krill were captured.

Thus it seems that both Bolocera tuediae and Pachycerianthus multiplicatus fulfil Roughgarden's (1975) first 2 criteria, i.e., by being easily found and not negatively affected by the crustacean symbionts. $B$. tuediae is also known to be long-lived, which gives further advantages to the symbionts. Most probably the anthozoans provide benefit to the crustaceans by offering protection under their tentacles, although further experiments are needed to quantify the degree of protection afforded. We often saw shrimp sifting through the sediment beneath $B$. tuediae with their pereiopods, presumably in search of food particles left from the feeding of the anemone or regurgitated by it. Thus, easy access to food may be another advantage for the crustaceans. The crab Inachus phalangium eats food regurgitated by a sea anemone and mucus from its surface, and even crops the tips of its host's tentacles (Wirtz \& Diesel 1983 in, Wirtz 1997). Our observations suggest that the symbiotic crustaceans have also developed a tolerance against the nematocysts, while other crustaceans lack this.

In the laboratory, the shrimp Pandalus borealis did not significantly avoid the bare substrate in favour of the anthozoan or the artificial anemone. This was consistent with observations in the field, where this species did aggregate around Bolocera tuedie, but was also seen in large numbers on the sediment bottom. This means that the symbiotic response of $P$. borealis is considerably weaker than the response of the other shrimps (e.g. Spirontocaris liljeborgii and Lebbeus polaris).

Individuals of the crab Lithodes maja, on the other hand, did show a symbiotic response also in the laboratory. This response was largely confined to the females, which chose shelter in preference to bare sand, and seemed also to prefer the real anthozoan to the artificial anemone. However, because of small sample size, this latter result remained only a weak trend ( $p=0.09$, $d f=9$ ). A similar sex-related response was observed in the tropical crab Inachus phalangium. Female crabs of this species stay with their particular host anemones, while the males move around at night, searching for females (Wirtz 1997). During our laboratory experiments, 1 of the smaller L. maja was observed among the tentacles on the oral disc of the anemone during the whole experiment, unmolested by 
the nematocysts. The anemone did not seem to be much disturbed by the crab, since it kept its tentacles retracted for a few minutes and later extended them again.

Crawford (1992) found that many tropical anemone fishes and anemone shrimps are usually not found separate from their hosts. However, the shrimp species associated with Bolocera tuediae and Pachycerianthus multiplicatus were all found living as non-symbionts as well, although Spirontocaris liljeborgii, and Lebbeus polaris were rarely observed far from an anthozoan. Thus, again, the association seemed more important to these 2 species than to Pandalus spp.

Most tropical shrimps are host-specific either to 1 or to a few species of anemones, suggesting that shrimps are capable of distinguishing between potential hosts and other anemones (Bruce 1976). The shrimps in our investigation were never observed beneath any anthozoan species other than Bolocera tuediae and Pachycerianthus multiplicatus, suggesting host-species-specificity for the shrimp-anthozoan associations in our study.

Tropical shrimp-anthozoan symbioses are usually viewed as commensalistic, as the shrimps derive benefits (food scraps and protection) from their hosts, without having any obvious effect on them (Shick 1991). A few associations have been found to be mutualistic, e.g., the snapping shrimp Alpheus armatus that associates with the anemone Bartholomea annulata: the shrimp chases away the polychaete Harmodice carunculata that would otherwise prey upon the anemone (Smith 1977). The association between the shrimp Periclemenes brevicarpalis and its host anemones have been found to be intermittently parasitic. In laboratory studies, $P$. brevicarpalis has been seen to tear tentacles from its host for food when deprived of other food sources (Fautin et al. 1995). Bolocera tuediae and Pachycerianthus multiplicatus did not seem to have any advantages or disadvantages from their associations with shrimps and crabs. Consequently, we suggest the observed associations to be commensalistic.

Acknowledgements. This work was supported by the World Wide Fund for Nature (WWF), Bingolotto/Återvinsten, the Bohuslän Regional Board, the Swedish Environmental Protection Agency, the County Board of Västra Götaland, the Philipson Family Foundation and the Centre of Excellence, TMBL. We thank G. Toth for helpful suggestions on an earlier version of the manuscript, K. Hill for valuable help with the language, P. Nilsson for statistical advice, and I. Adolfsson and H. Mott for assistance in the field. The staff at Tjärnö Marine Biology Laboratory gave general support.

\section{LITERATURE CITED}

Bruce AJ (1976) Shrimps and prawns of coral reefs, with special reference to commensalism. In: Jones OA, Endean R (eds) Biology and geology of coral reefs, Vol 3. Academic Press, New York, p 37-94

Crawford JA (1992) Acclimation of the shrimp, Periclimenes anthophilus, to the giant sea anemone, Condylactis gigantea. Bull Mar Sci 50(2):331-341

Dahl E (1960) Koralldjur. In: Hanström B (ed) Djurens Värld, Ryggradslösa djur. Förlagshuset Norden AB, Malmö, p 315-331

Fautin DG, Guo CC, Hwang JS (1995) Costs and benefits of the symbiosis between the anemoneshrimp Periclimenes brevicarpalis and its host Entacmaea quadricolor. Mar Ecol Prog Ser 129:77-84

Howard FG (1982) Of shrimps and sea anemones; of prawns and other things. Scott Fish Bull 47:39-40

Manuel RL (1981) British Anthozoa. In: Kermack DM, Barnes RSK (eds) Synopsis of the British fauna, No 18. Academic Press, London, p 67-104

O'Connor B, Könnecker G, McGrath D, Keegan BF (1977) Pachycerianthus multiplicatus - biotope or biocoensis? In: Keegan BF, Ceidigh PO, Boaden PJS (eds) Biology of benthic organisms. Pergamon Press Ltd, Oxford, p 475-482

Ross DM (1971) Protection of hermit crabs (Dardanus spp) from octopus by commensal sea anemones (Calliactis spp). Nature 230:401-402

Roughgarden J (1975) Evolution of marine symbiosis-a simple cost-benefit model. Ecology 56:1201-1208

Shick JM (1991) A functional biology of sea anemones. Chapman \& Hall, London

Smith VL (1977) Beneficial behaviour of a symbiotic shrimp to its host anemone. Bull Mar Sci 27:87-98

Sokal RR, Rohlf FJ (1995) Biometry. The principles and practice of statistics in biological research, 3rd edn. WH Freeman \& Co, New York

Stevens BG, Anderson PJ (1999) An association between the anemone Cribrinopsis fernaldi, and shrimps of the families Hippolytidae and Pandalidae. Northwest Atlantic Fisheries Organization, Scientific Council Meeting (Serial No N4153), Dartmouth, p 1-7

Underwood AJ (1997) Experiments in ecology. Cambridge University Press, Cambridge

Vader W (1970a) Amphipods associated with the sea anemone Bolocera tuediae, in western Norway. Sarsia 43: 87-98

Vader W (1970b) Antheacheres duebeni, a copepod parasitic in the sea anemone Bolocera tuediae. Sarsia 43:99-106

Wirtz P (1997) Crustacean symbionts of the sea anemone Telmatactis cricoides at Madeira and the Canary Islands. J Zool 242:799-811

Submitted: July 26, 1999; Accepted: July 27, 2000

Proofs received from author(s): December 7, 2000
Editorial responsibility: Otto Kinne (Editor),

Oldendorf/Luhe, Germany 